\title{
Transintegumentary Uptake of Dissolved Amino Acids in the Sea Star Asterias rubens. A Reassessment of its Nutritional Role with Special Reference to the Significance of Heterotrophic Bacteria
}

\author{
D. Siebers \\ Biologische Anstalt Helgoland, Palmaille 9, D-2000 Hamburg 50, Federal Republic of Germany
}

\begin{abstract}
Sea stars Asterias rubens of about $1.5 \mathrm{~g}$ body weight were exposed to different nutritional conditions. Experimentals received soft parts of mussels Mytilus edulis as particulate food; controls were starved. In order to determine the nutritive significance of epidermal amino-acid uptake in terms of body-weight changes, 3 concentrations $(10,30,90 \mu \mathrm{M})$ of a natural amino-acid mixture were offered. The sea stars were kept at $15^{\circ} \mathrm{C}$ in $1 \mathrm{l}$ of sea water, which was renewed daily. At an ambient concentration of $90 \mu \mathrm{M}$ amino acids, body-weight increases were observed during 3-4 weeks, not differing greatly from weight increases of sea stars fed mussel meat. Subsequent weight losses in these two groups could be attributed mostly to poor water quality resulting from bacterial contamination. The experimentals offered $10 \mu \mathrm{M}$ amino acids did not differ significantly from the starved controls; both groups steadily reduced their body weights. Weight decreases of sea stars maintained at an ambient concentration of $30 \mu \mathrm{M}$ were less than those of starved controls. Microbial populations reacted to the dissolved amino acids offered within a few hours, exhibiting rapid absorption and increased multiplication. Maintenance of asteroids in sea water together with bacteria, which had been allowed to grow for some days on a $10 \mu \mathrm{M}$ natural amino-acid mixture, and subsequent net influx analysis revealed that uptake of dissolved amino acids is primarily a bacterial process. The data obtained do not provide evidence that, in $A$. rubens, epidermal amino-acid uptake significantly contributes to metabolic energy demands.
\end{abstract}

\section{INTRODUCTION}

Although mechanisms of heterotrophy have received considerable attention in 'Marine Ecology' (e.g. Volume II: Pandian, 1975; Volume IV: Conover, 1978), the ecological significance of epidermal nutrient uptake has remained a controversial issue. Transintegumentary absorption of low molecular weight organic matter, which is dissolved in varying, but always very low concentrations in natural fresh and sea water, has been demonstrated in a considerable number of marine invertebrates (cf. Stephens, 1972; Jørgensen, 1976). Recently, Southward et al. (1979) have summarized the literature of the past seven years. There is ample experimental evidence that dissolved organic substances - most experiments deal with amino acids, carbohydrates and organic acids - are actively transported across the epidermis against concentration gradients of several orders of magnitude at the cost of biological energy. Calculations of the nutritional profit obtained from solute absorption can be performed by means of concentration-dependent net influx velocities, the calorific contents of the substances taken up, and estimates of oxygen uptake rates of the species considered. The results are expressed as percentage of energy equivalent to $\mathrm{O}_{2}$-consumption. Calculations of this type have been the basis for the assumption that dissolved organic matter may represent an additional and in some cases substantial nutritive source for a variety of soft-bodied members of the invertebrate kingdom (Taylor, 1969; Southward \& Southward, 1972; Stephens, 1972, 1975; Stephens et al., 1978; Sorokin \& Wyshkwarzev, 1973; Schlichter, 1975; Siebers \& Bulnheim, 1977).

However, the above-mentioned assumption is far from being generally adopted. Jørgensen (1976) argues that in contrast to the situation of infaunal sediment-dwellers epifaunal and pelagic invertebrates in the unpolluted sea-water column seemingly cover only small to insignificant fractions of their total 
energy requirements from uptake of dissolved amino acids, because of too low ambient concentrations. Presumably, heterotrophic micro-organisms are far more important than animals in metabolizing and recycling dissolved organic matter (for reviews consult Marine Ecology', Volume IV, especially Wangersky, 1978 and Sorokin, 1978). According to Sepers (1977) heterotrophic bacteria are much better adapted to the very low substrate concentrations, as shown by their small transport constants. Uptake of dissolved organic matter in natural waters seems to be primarily a bacterial process.

The present paper aims to contribute to the question of the nutritional significance of epidermal amino-acid uptake by means of experiments which exceed shortterm uptake analyses of a few hours and attempt to improve the present comprehension obtained from formal calculations of nutritional profit by taking into account simultaneous utilization of dissolved organic matter by external invertebrate surfaces and heterotrophic bacteria. The sea star Asterias rubens serves as suitable object; sufficient information is available on echinoderm nutrition by means of processing particulate food within alimentary canals (cf. Anderson, 1966) and from solute absorption across the body surfaces (Stephens and Schinske, 1961; Stephens and Virkar, 1966; Ferguson, 1967a, b, 1969, 1970, 1971; Fontaine \& Chia, 1968; Péquignat, 1969, 1972; Pearse \& Pearse, 1973; Aheam \& Townsley, 1975; de Burgh et al., 1977; Stephens et al., 1978).

\section{MATERLALS AND METHODS}

Sea stars Asterias rubens of wet weights between 1 and $2 \mathrm{~g}$ were obtained from the Littoral Station of the 'Biologische Anstalt Helgoland' in List on the island of Sylt (North Sea). In the laboratory, the sea stars were maintained in filtered sea water and fed small pieces of the soft parts of the mussel Mytilus edulis. All experiments were performed at a temperature of $15^{\circ} \mathrm{C}$ and a salinity of $35 \%$. The sea water used was taken

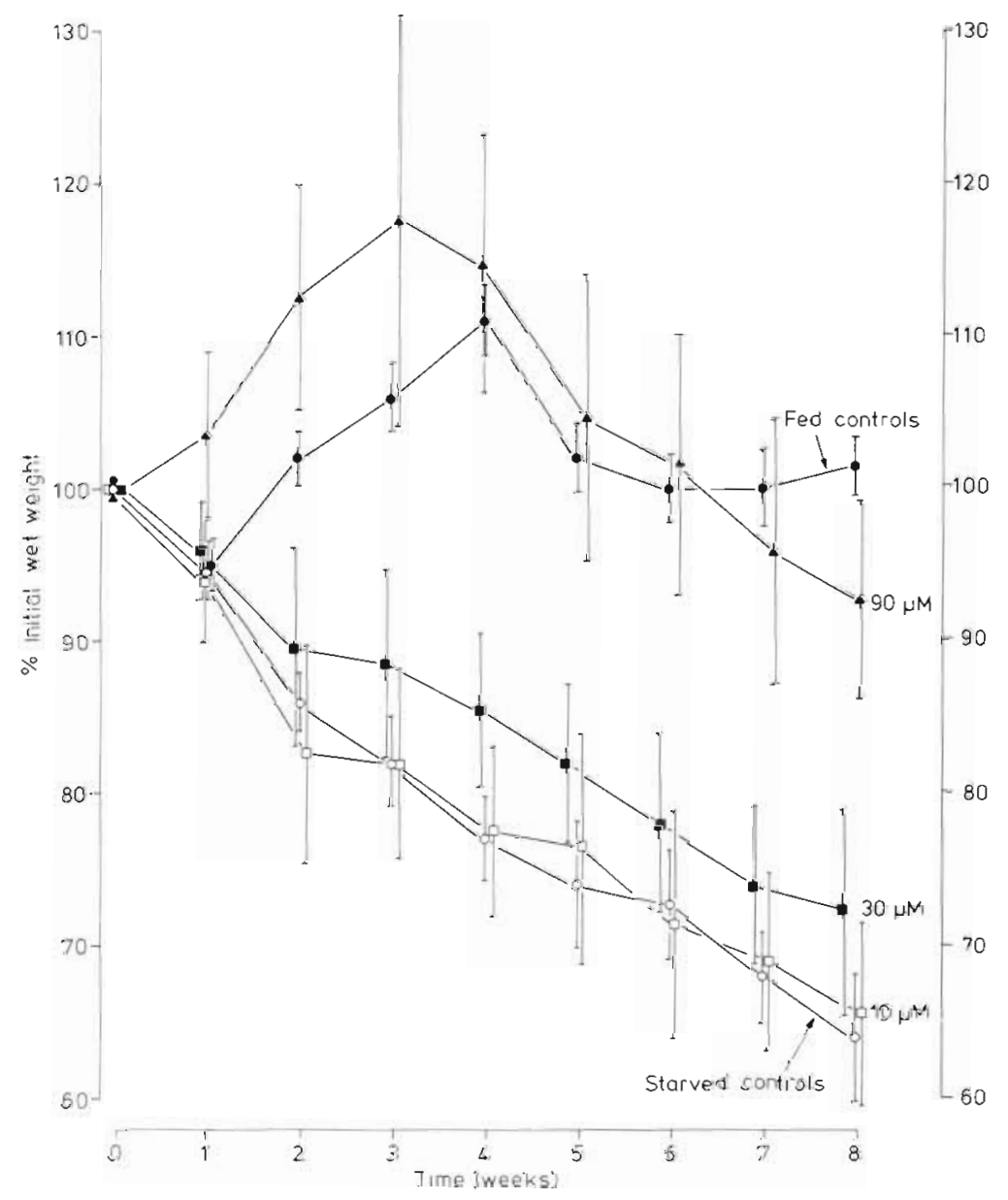

Fig. 1. Asterias rubens. Development of wet weight in relation to nutrient availability. Each experimental group comprises 12 sea stars of about $1.5 \mathrm{~g}$ initial weight. The test individuals were maintained in a volume of $1 \mathrm{l}$ of 'sea water contaminated with bacteria', which was renewed daily. For the nutritive conditions of the test groups consult section 'Materials and Methods' 
from near the island of Helgoland. It had been aged at room temperature in storage tanks without access of light or oxygen for about half a year. Before use it was aerated and ran over gravel filters in circuit for at least 2 weeks. For this water we use the term 'sea water of low bacterial activity' (Figs 3-6, Table 1).

Experiments analysing the dependence of bodyweight development on the availability of particulate food or dissolved amino acids comprised controls fed with mussel meat, starved controls, and 3 other groups, exposed to concentrations of 10,30 and $90 \mu \mathrm{M}$ of an amino-acid mixture. This mixture was composed as reported by Dawson and Pritchard (1978) for samples of sea water collected from different depths in the open Baltic Sea. The composition of samples from the North Sea (Bohling, 1970, 1972) deviated only slightly from

Table 1. Development of bacterial numbers in sea-water samples enclosing a sea star and in controls. The sea water was initially enriched with $10 \mu \mathrm{M}$ of a natural amino-acid mixture. The initial concentration was filled up again after appropriate decreases due to transepidermal absorption by sea stars and/or heterotrophic bacterial uptake as demonstrated in Figure 6

\begin{tabular}{|c|c|c|}
\hline $\begin{array}{l}\text { Hours after } \\
\text { start of } \\
\text { experiment }\end{array}$ & $\begin{array}{c}\text { Bacterial numbers } \mathrm{ml}^{-1} \text { in } \\
\text { sea-werter samples enclo- } \\
\text { sing a sea star }\end{array}$ & $\begin{array}{c}\text { Bacterial numbers } \\
\mathrm{ml}^{-1} \text { in controls }\end{array}$ \\
\hline $0-$ start & $6.310^{2}$ & $6.3 \cdot 10^{2}$ \\
\hline 24 & $1.810^{4}$ & $4.1 \quad 10^{4}$ \\
\hline 48 & $1.110^{6}$ & $10^{6}$ \\
\hline 72 & $1.3 \cdot 10^{6}$ & $2.310^{6}$ \\
\hline
\end{tabular}

the Baltic samples. The actually applied amino-acid storage mixture contained (in mmoles $\mathrm{l}^{-3}$ ): L-aspartic acid 14, L-threonine 10, L-serine 38, L-glutamic acid. 16, glycine 42, L-alanine 24, L-valine 6, L-isoleucine 4, L-leucine 6, L-tyrosine 2, L-phenylalanine 4, L-ornithine 18, L-lysine 6, L-histidine 4, L-arginine 4, and Lcysteine 2. Each sea star tested was maintained in a water volume of $1 \mathrm{l}$ and transferred daily to fresh seawater contained in cleaned glass vessels. Once a week the test animals were weighed to the nearest milligram after removal of adhering water on filter paper for $3 \mathrm{~min}$. Also once a week the concentration of amino acids was measured prior to the daily water renewal. The experiment was terminated after a period of 8 weeks with the determination of dry weights. These experiments were performed in 'sea-water contaminated with bacteria' (Figs 1 and 2), as described in detail under 'Results'.

The second set of experiments, which lasted between 3 and $68 \mathrm{~h}$, examined net uptake of individual amino acids and the amino-acid mixture mentioned above. At appropriate intervals $1-\mathrm{ml}$ samples were taken from the incubation medium, which contained the sea stars, and from the control media. After addition of $0.035 \mathrm{ml}$ of potassium borate buffer $\mathrm{pH} 10.4$
(Durrum), $0.25 \mathrm{ml}$ of fluorescamine (Sigma) reagent (200 $\mathrm{mg} \mathrm{l}^{-3}$ acetone), and $1 \mathrm{ml}$ distilled water, fluorescence was measured in an Aminco fluorometer with $10 \mu \mathrm{M}$ glycine as standard (North, 1975; Stephens, 1975).

Samples of $0.2 \mathrm{ml}$ of sea-water were withdrawn, in order to measure the radioactivity of $10 \mu \mathrm{M}{ }^{14} \mathrm{C}$-alanine (Amersham) which was added to obtain a specific activity of $1 \mu \mathrm{Ci} \mu \mathrm{mole}^{-1}$ in incubation and control media.

The samples were acidified to $\mathrm{pH} 1.0$ with $0.3 \mathrm{ml}$ dilute hydrochloric acid and gently shaken at room temperature for $3 \mathrm{~h}$ to remove respired ${ }^{14} \mathrm{CO}_{2}$. After addition of $5 \mathrm{ml}$ counting solution (Rotiscint 22, Roth, Karlsruhe, FRG), the samples were assayed for ${ }^{14} \mathrm{C}$ label in a liquid scintillation counter (Prias, Packard) with quench corrections by external standard channels ratio.

Estimations of bacterial densities were performed after appropriate dilutions of sea-water samples and spreading of $100 \mu \mathrm{l}$ volumes on marine agar plates. Colonies were allowed to develop for 5 days at about $20^{\circ} \mathrm{C}$ and were then counted.

\section{RESULTS}

\section{Body-Weight Development}

Individuals maintained without particulate food or dissolved nutrients gradually reduced their wet weights within a period of 8 weeks to $64 \%$ of their initial body-weights (Fig. 1). There was no difference between these starved controls and a group kept in sea water enriched with $10 \mu \mathrm{M}$ of a natural amino-acid mixture, which was renewed daily. Weight development in an ambient amino-acid concentration of $30 \mu \mathrm{M}$ revealed attenuation of weight loss when compared to the starved controls or the $10-\mu \mathrm{M}$ group. The controls fed with about $100 \mathrm{mg} \mathrm{d}^{-1}$ of mussel meat increased their body weights up to the 4 th week to $111 \%$ of their initial weights and showed weight loss thereafter. The sea stars kept in $90 \mu \mathrm{M}$ amino acids had the strongest wet-weight increases $(118 \%)$ up to the 3 rd week, followed by a weight decrease. The dry weights, determined after 8 weeks, amounted to $31.8 \pm 1.5 \%$ of wet weight for starved controls, $29.9 \pm 2.4$ for fed controls, $31.7 \pm 1.5$ for the group maintained at $10 \mu \mathrm{M}$ amino acids, $31.0 \pm 2.0$ for $30 \mu \mathrm{M}$, and $26.3 \pm 3.2$ for the 90 $\mu \mathrm{M}$ group.

Three weeks after the start of the experiments, the amounts of amino acids which had been taken up by the sea stars were estimated. Amino-acid assays were performed just after a water exchange and 24 h later, immediately before the next water exchange. Within 


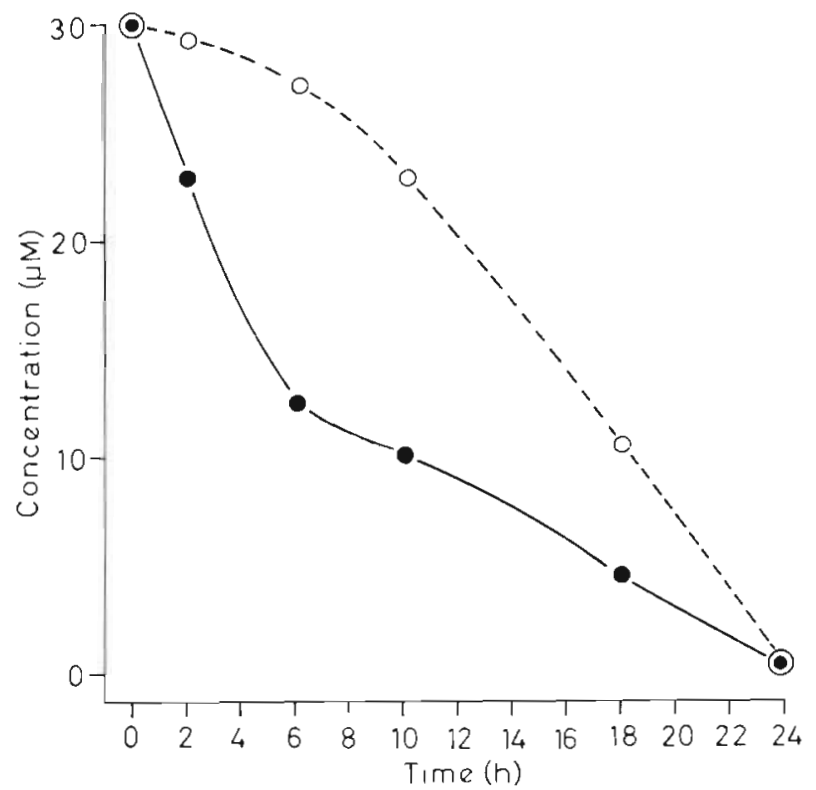

Fig. 2. Asterias rubens. Net fluxes of a natural amino-acid mixture across the body surface (closed circles) and disappearance of amino-acids in controls (open circles). Identical volumes were taken from 12 vials containing a sea star (about $1 \mathrm{~g}$ wet weight $l^{-1}$ of 'sea water contaminated with bacteria') and

combined before the fluorescence assay for amino acids

$24 \mathrm{~h}$ the concentrations of dissolved amino acids were reduced from 10,30 , and $90 \mu \mathrm{M}$ to levels which varied considerably, but were in most cases below $1 \mu \mathrm{M}$. In starved controls concentrations after $24 \mathrm{~h}$ presence of sea stars never exceeded $0.1 \mu \mathrm{M}$, but in fed controls sometimes values as high as $2 \mu \mathrm{M}$ occurred, possibly due to losses during feeding.

To follow 24-h concentration dynamics in the $30-\mu \mathrm{M}$ group, identical volumes were taken from every container of a sea star and pooled. Individual amino-acid determinations could not be made, because the weight-water relations (about $1 \mathrm{~g} \mathrm{l}^{-3}$ ) were not identical and varied with the duration of the experiments. A typical pattern is shown in Figure 2. As mentioned above, the amino-acid concentration decreased steadily to values close to zero, but this was the same in controls with no sea star present. The amino-acid decrease in controls initially proceeded slower than in water withdrawn from sea star containers, but faster after a lag phase of about $6 \mathrm{~h}$, finally reaching the same low value. These findings suggest that part of the decrease was due to bacterial activity, but that under these conditions, a defined proportion of the aminoacid decrease - the area between the upper and the lower curve in Figure 2 - may be attributable to transepidermal net influx.

This high bacterial activity, indicated by nearly total amino-acid disappearance also in the absence of sea stars (controls), may be explained as follows. $60 \mathrm{l}$ water had to be taken daily for 5 groups of 12 sea stars from a
600-1 reservoir of permanently filtered "sea water of low bacterial activity" (see 'Methods'). After it had been realized that nearly no amino acids were present in samples withdrawn from containers of sea stars following their 24 -h presence, $12 \mathrm{l}$ of sea-water from the $10-\mu \mathrm{M}$ group and $12 \mathrm{I}$ from the starved controls were recycled to the 600-l reservoir every day, and only 361 were renewed daily from the storage tank. As became clear during the experiment, this procedure did not introduce amino acids into the experimental water but, as seen from Figure 2, a certain amount of bacteria. This is why I use the term sea water contaminated with bacteria', in the experiments concerning wetweight development.

\section{Amino-Acid Net Fluxes}

Transepidermal net flux of the amino-acid mixture and glycine (Fig. 3) was investigated in a small amount of aerated 'sea water of low bacterial activity' $(75 \mathrm{ml}$ of sea water $\mathrm{g}^{-1}$ wet weight) over $4 \mathrm{~h}$. During this period the initial concentration of $10 \mu \mathrm{M}$ was reduced to $1.7 \mu \mathrm{M}$ (glycine) and $4 \mu \mathrm{M}$ (amino-acid mixture). The presence of $20 \mathrm{mg} \mathrm{l}^{-1}$ streptomycine sulfate did not significantly effect the absorption of glycine. In controls without sea stars or controls containing streptomycine sulfate the initial glycine concentration was reduced only insignificantly, implying that bacterial uptake did not contribute essentially to the net flux rates measured. It is this type of net flux curve, which has been used to demonstrate lacking bacterial participation in the uptake process.

Quite different results are obtained if the experimental time is extended from 4 to $48 \mathrm{~h}$, and the weightwater relation changed from $75 \mathrm{ml} \mathrm{g} \mathrm{g}^{-1}$ (Fig. 3) to $250 \mathrm{ml} \mathrm{g}^{-1}$ wet weight, also using sea water of low bacterial activity' (Fig. 4). The amino-acid mixture in vials containing a sea star is reduced from $10 \mu \mathrm{M}$ to 0.5 , i. e. $1 \mu \mathrm{M}$ within $24-30 \mathrm{~h}$. However, after a lag phase, amino acids are reduced also in controls to comparatively low values within about the same period $(30 \mathrm{~h})$. There is also an area between the upper and lower curve, which represents the proportion of the total net flux attributable to absorption by the sea star. In controls of $10 \mu \mathrm{M}$ alanine and the amino-acid mixture, which had been sterilized by exposure to $80^{\circ} \mathrm{C}$ for $12 \mathrm{~h}$ on two successive days, the initial concentrations remained almost unchanged.

The results reported in the preceding paragraph are also valid for an individual neutral amino acid. The concentration dynamics of $10 \mu \mathrm{M}$ unlabeled and $10 \mu \mathrm{M}$ ${ }^{14} \mathrm{C}$-alanine are shown in Figure 5. In sterilized sea water, which has also been used for about 5 subsequent washings of the sea stars prior to experimental 


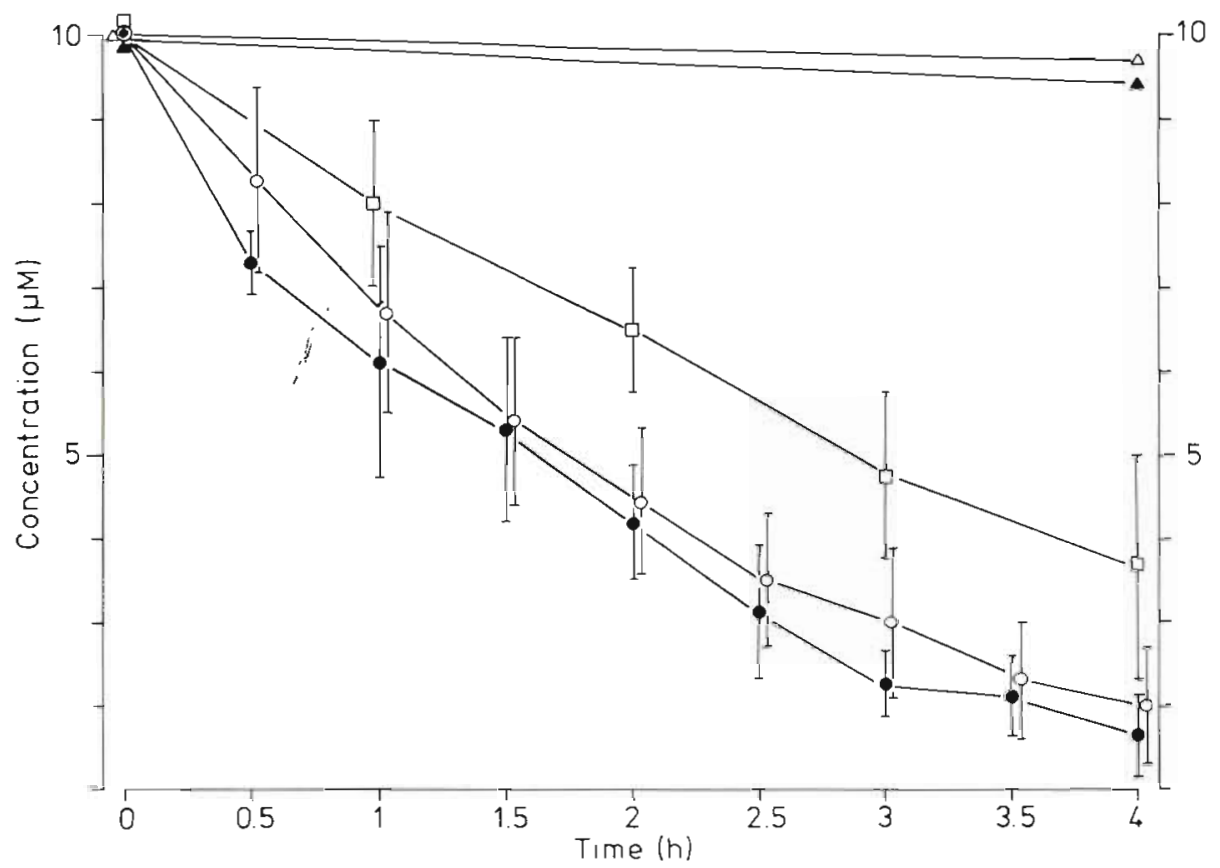

Fig. 3. Asterias rubens. Net flux of a natural amino-acid mixture (open squares) and glycine in the presence (open circles) and absence (closed circles) of $20 \mathrm{mg} \mathrm{l}^{-1}$ streptomycine sulfate. Controls were performed with (open triangles) and without (closed triangles) the antibiotic. The number of replicates was $n=6$, and the weight-water relation $75 \mathrm{ml}$ aerated sea water of low bacterial activity' $\mathrm{g}^{-1}$

use, the concentration of alanine or ${ }^{14} \mathrm{C}$ label remained unchanged in controls, indicating that no or negligible bacterial activities had developed within $48 \mathrm{~h}$ (Fig. 5, II $B$ and IV B). Hence, the total uptake measured must have resulted from net transport activities of the sea star (Fig. 5, II A and IV A). After $12 \mathrm{~h}$ of the presence of a sea star, $25 \mathrm{ml}$ of its ambient medium were withdrawn and used for a second set of controls (Fig. 5, II C and IV C). Concentrations of alanine and ${ }^{14} \mathrm{C}$-radioac- tivity were not significantly altered, suggesting that the sea stars had not introduced heterotrophic microorganisms capable of producing measurable activities. The uptake curves resulting from experiments initially started with 'sea water of low bacterial activity', are quite similar (Fig. 5, II and III), but they are obviously due to asteroid uptake plus heterotrophic microbial absorption (controls, Fig. 5, I B and III B). Also, the second set of controls (Fig 5, I C and III C) indicates

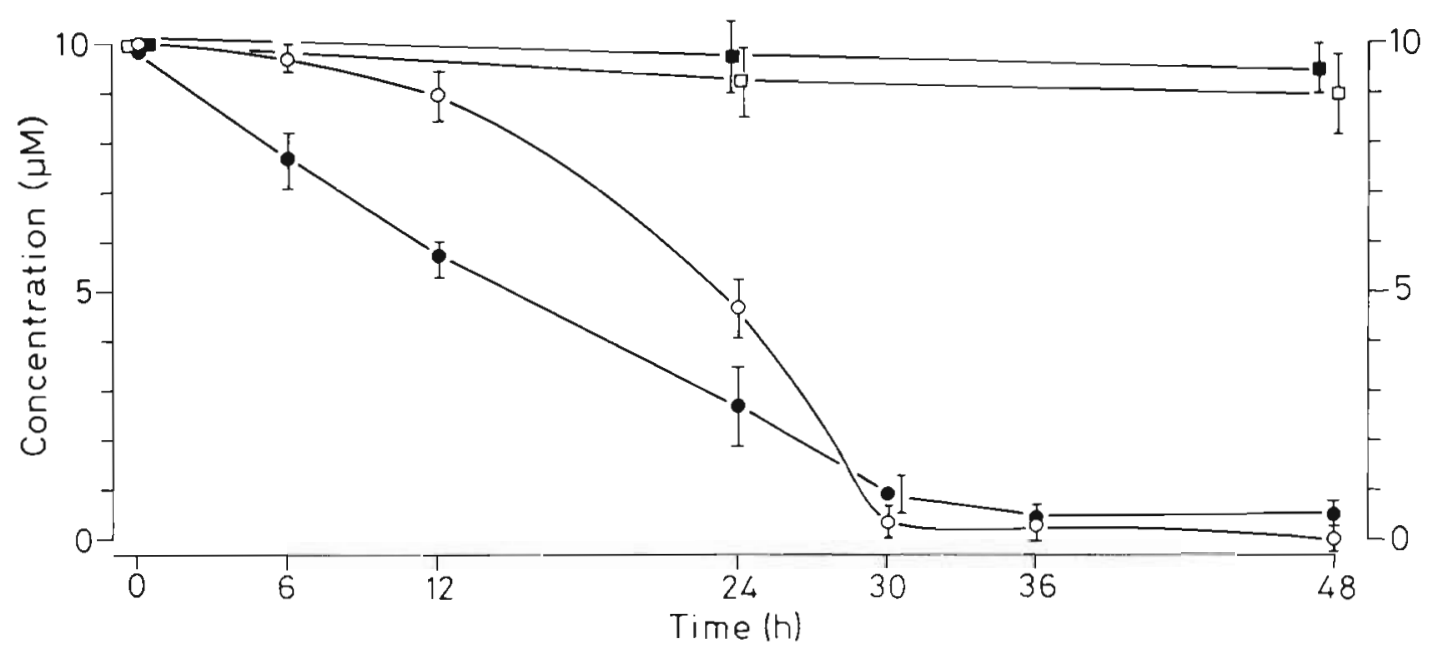

Fig. 4. Asterias rubens. Transepidermal net uptake (closed circles) of a natural amino-acid mixture and bacterial uptake in controls (open circles, see text) within $48 \mathrm{~h}$. The sterilized $\left(2 \times 12 \mathrm{~h} 80^{\circ} \mathrm{C}\right)$ controls were enriched with $10 \mu \mathrm{M}$ amino-acid mixture (closed squares) and $10 \mu \mathrm{M}$ alanine (open squares). The number of replicates was $\mathrm{n}=5$, and the weight-water relation was $250 \mathrm{ml}$ 'sea water of low bacterial activity' $\mathrm{g}^{-1}$ wet weight 

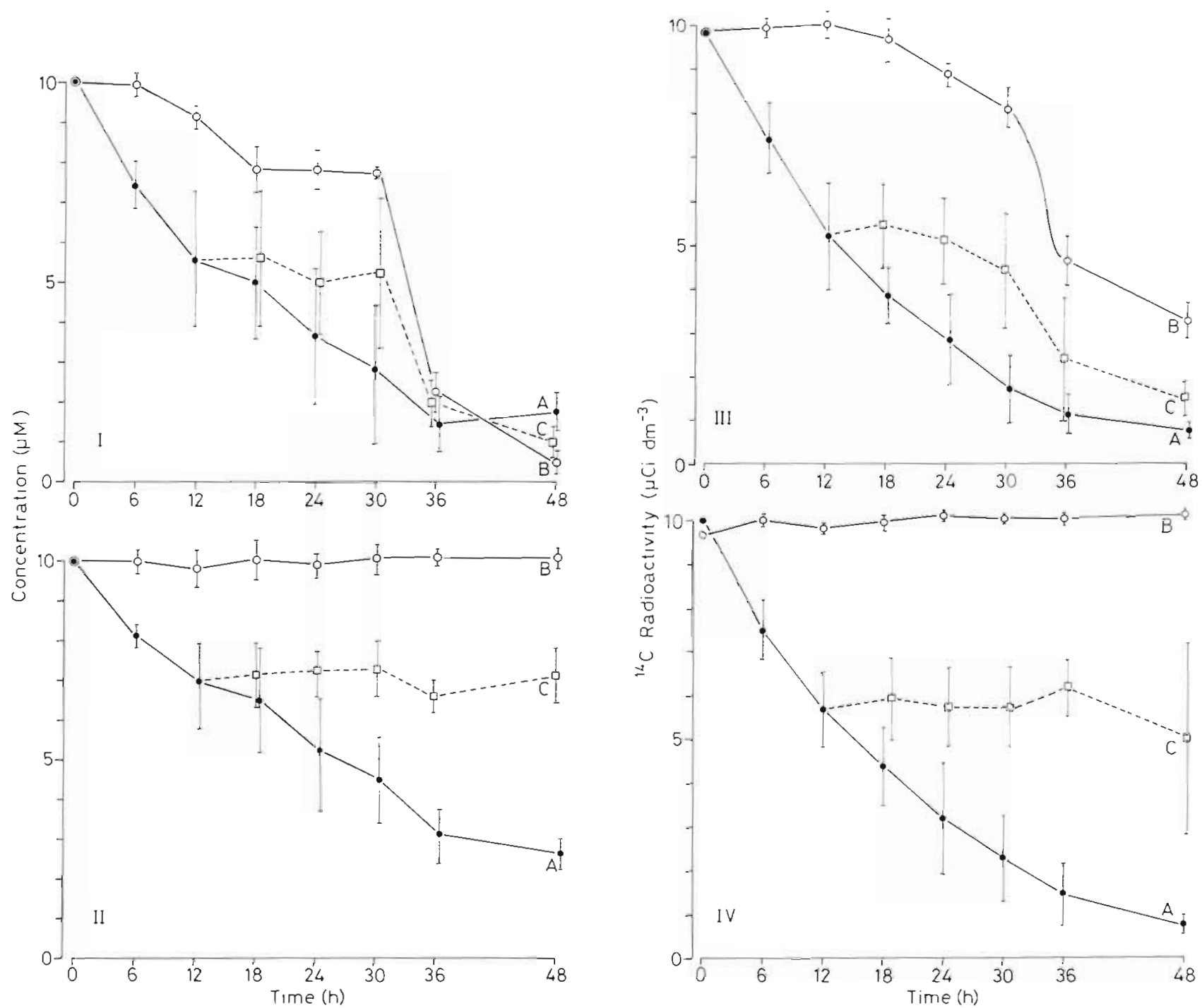

Fig. 5. Asterias rubens. Transepidermal net absorption of L-alanine ( $\mathrm{I}, \mathrm{II})$ and concentration development of radioactivity from ${ }^{14} \mathrm{C}$-alanine (III, IV). Experiments were performed in 'sea water of low bacterial activity' (I, III) and sterilized $\left(2 \times 12 \mathrm{~h} 80{ }^{\circ} \mathrm{C}\right)$ sea water (II, IV). Sea stars (A, closed circles) are compared to controls (B, open circles) and a second set of controls (C, open squares), withdrawn from containers of sea stars $12 \mathrm{~h}$ after the experiment had started. The number of replicates was $\mathrm{n}=6$, and the weight-water relation was $1 \mathrm{lg}^{-1}$

bacterial activities, when compared to the results obtained from experiments performed in sterile sea water.

When the initial concentration of $10 \mu \mathrm{M}$ amino acids, after appropriate reductions due to heterotrophic absorption, is filled up again by the experimentor, imitating 'production' of dissolved organic matter, the role of bacteria in relation to the sea stars becomes quite obvious (Fig. 6). At the beginning of the experiment, the reduction of the amino-acid mixture from $10 \mu \mathrm{M}$ to $3.8 \mu \mathrm{M}$ (sea stars) and $7.3 \mu \mathrm{M}$ (controls) lasted $30 \mathrm{~h}$, and a defined proportion of the total amino-acid decrease could be attributed to the uptake activity of the sea star. After filling up the concentrations to
$10 \mu \mathrm{M}$ again, the two uptake curves obtained from vials containing a sea star and from controls did not differ, indicating that the greater proportion of the uptake now, about $30 \mathrm{~h}$ after beginning the experiment, was due to bacterial activities. The time of initially $30 \mathrm{~h}$, which passed until a reduction of amino acids from 10 to $3.8 \mu \mathrm{M}$ and $7.3 \mu \mathrm{M}$ (controls) became obvious, decreased considerably, and after about $3-4$ days only about 3-4h were needed for amino-acid decreases to about $1.8 \mu \mathrm{M}$. These findings suggest that nearly the total uptake measured now resulted from heterotrophic microbial activities.

These results are consistent with the measured numbers of heterotrophic bacteria (Table 1), which increase 


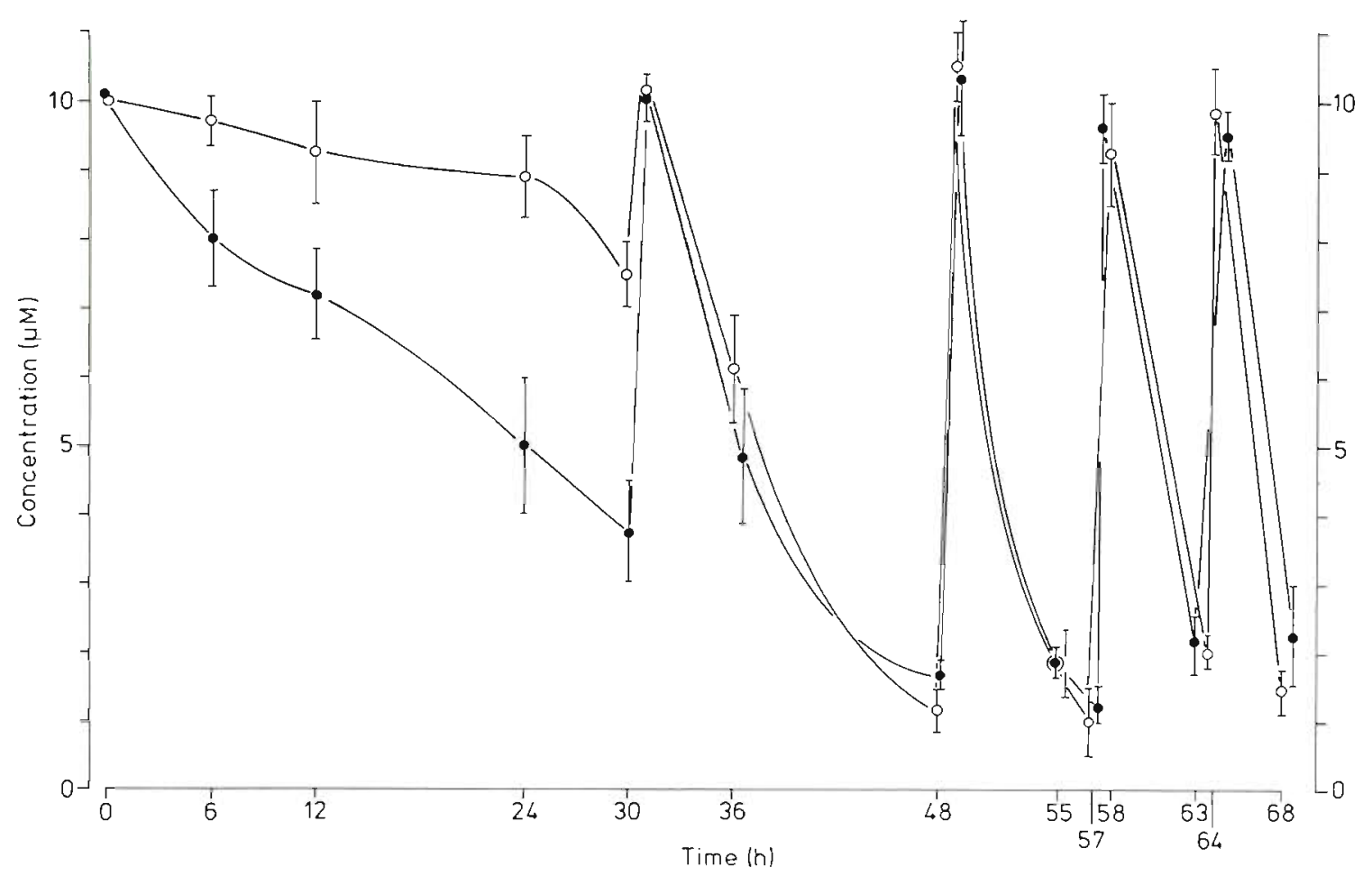

Fig. 6. Asterias rubens. Transepidermal net flux (closed circles) of $10 \mu \mathrm{M}$ amino-acid mixture and concentration development in controls (open circles). The amino-acid concentration was monitored, and after appropriate decreases filled up again to $10 \mu$ at $30,48,58$ and $64 \mathrm{~h}$. For development of bacterial activities see Table 1. The experiment was started with sea water of low bacterial activity' ( $\mathrm{n}=4$ ) with a weight-water relation of $1 \mathrm{lg}^{-1}$ body weight

from initially $6.3 \times 10^{2} \mathrm{ml}^{-1}$ ('sea water of low bacterial activity') to $1.3 \times 10^{6}$ (sea stars) and $2.3 \times 10^{6}$ (controls). Whether or not increased bacterial numbers in controls as compared to samples obtained from sea stars result from antimicrobial activities of the asteroid, is still an open question.

\section{DISCUSSION}

\section{Body-Weight Development}

The experiments reported have originally been designed to determine the amino-acid concentration at which weight gain of sea stars could be observed, or a body-weight development became obvious, which significantly differed from that of starved controls. Stephens et al. (1978) concluded that if the sea star Dendraster excentricus is exposed to amino-acid levels of $35 \mu \mathrm{M}$ and higher, the influx is sufficient to account for oxygen consumption.

At an ambient amino-acid level of $90 \mu \mathrm{M}$, wet weights increased within the first 3 weeks, not differing from fed controls. However, these sea stars soon showed an intense reddish colour and extruded their whole tube feet areas. The water, as a rule, became murky overnight. Considerable mortalities in the 90 $\mu \mathrm{M}$ group after a period of 8 weeks led to termination of the experiment. These phenomena could also be observed, however less pronounced, at the ambient concentration of $30 \mu \mathrm{M}$. At these amino-acid levels heavy bacterial contamination (Fig. 2) may have resulted in a hostile environment, inducing the adverse effects and mortalities mentioned.

At 30 and $90 \mu \mathrm{M}$, supplied daily in a volume of 11 sea water containing bacteria, the sea stars obtained certain amounts of nutrients for some time as seen from their body-weight development.

Sea stars tend to firmly attach themselves with their tube feet to container walls. This interferes with handfeeding. While in the first 4 weeks food was accepted readily, the sea stars progressively failed to cooperate over longer periods of time. This and poor water quality due to adverse effects of excretory products may have contributed to the weight losses observed.

\section{Heterotrophic Bacteria}

Our experiments were not performed in sterile sea water but in sea water containing bacteria. Ecologically valid extrapolations are more difficult to make on 
the basis of experiments performed with sterilized or artificial sea water prepared from reagent grade inorganic salts.

The sterilized sea water $\left(2 \times 12 \mathrm{~h} 80^{\circ} \mathrm{C}\right.$, Figs 4 and 5) used in our experiments contained no viable bacteria. 'Sea water of low bacterial activity' - stored for half a year without access of light and oxygen and filtered for about 2 weeks in absence of nutrients before use (Figs 3-6) - contained 630 bacteria $\mathrm{ml}^{-1}$ (Table 1 ). As is well known, bacteria may survive for weeks and even months in a resting state until contact is made with a suitable substrate. The concentration of heterotrophic microorganisms in unsterilized sea water (Figs 1,2 ) is not known. The rate of amino acid decrease suggests roughly $10^{4}-10^{5} \mathrm{ml}^{-1}$. The numbers of heterotrophic bacteria (up to several $10^{6} \mathrm{ml}^{-1}$ ) determined during the experiment (Fig. 6, Table 1) coincide with data on natural populations of saprophytes (Gocke, 1976).

As shown in Table 1, heterotrophic microorganisms almost instantly react to suitable nutritive substrates with rapid uptake and multiplication (Gocke, 1976, 1977; Button, 1978). According to Williams and Gray (1970) bacterial populations respond to elevated amino-acid levels within about $30 \mathrm{~h}$ (see also Table 1 and Fig. 6). In the euphotic zone turnover rates of the easily degradable fraction of dissolved organic matter are often in the range of hours or a few days (Andrews and Williams, 1971; Williams et al., 1976). Maximum heterotrophic uptake velocities at elevated water temperatures fall together with chlorophyll and phytoplankton maxima in the period between spring and autumn (Gocke, 1977).

\section{Amino-Acid Net Fluxes}

The results shown in Figure 3 indicate that Asterias rubens possesses the capacity for net uptake of most of the amino acids contained in the mixture offered. However, these results, obtained with a low water/ body-weight relation of $75 \mathrm{ml} \mathrm{g}^{-1}$ during a short experimental period of $4 \mathrm{~h}$ cannot, without further qualification, be extrapolated to the situation prevailing in the natural habitat. The period of $4 \mathrm{~h}$ is shorter than lag phases of bacterial populations. Application of antibiotics is under these circumstances meaningless.

The curves in Figures 4-6 were obtained over longer experimental periods of up to $70 \mathrm{~h}$ in a larger volume of water $\left(0.25-1 \mathrm{lg}^{-1}\right)$. They imply that data obtained in artificial or sterile sea water are unlikely to reflect in situ conditions. An ambient amino-acid level as high as $10 \mu \mathrm{M}$ will probably not occur - or only over a short period - together with so few heterotrophic bacteria (controls in Fig. 3) that the sea star can successfully absorb quantities of amino acids sufficient to account for a substantial proportion of its oxygen uptake.

Increasing bacterial activities following elevated amino-acid levels are documented in Figure 6 and Table 1. If the water is 'spiked' several times with a concentrated amino-acid mixture to reach levels of $10 \mu \mathrm{M}$, which had been reduced by heterotrophic activity of bacteria and the asteroid, then bacterial numbers and the corresponding rates of microbial uptake increase markedly.

In the field, rapid and efficient heterotrophic microbial absorption probably tends to keep ambient aminoacid levels very low. As reviewed by Dawson and Pritchard (1978) average concentrations of total dissolved amino-acids in open ocean water amount to about $20 \mu \mathrm{g} \mathrm{l}^{-3}(0.2 \mu \mathrm{M})$ and lower.

At these low concentrations absorption rates of epibenthic and pelagic invertebrates are generally so small that only an insignificant proportion of oxygen consumption can be accounted for by integumentary transport processes.

Permanently low in situ amino-acid levels due to rapid bacterial reactions to the availability of suitable substrates are the main reason for our assumption that in Asterias rubens epidermal amino-acid uptake does not significantly contribute to covering metabolic expenses.

Future ecological investigations of epidermal absorption of dissolved organic matter across invertebrate body surfaces should take into account the predominant role of heterotrophic microorganisms.

Regarding the significance of transintegumentary solute uptake Jørgensen (1976) stresses that the majority of publications deals with uptake in nutritional terms. Another, more general interpretation is that the transport processes observed reflect general cell-membrane properties; this interpretation is consistent with the vestigial nature of the transport systems (Jørgensen, 1976).

Acknowledgements. I would like to thank Dr. G. Hentzschel and Mrs. U. Kebernik for the analysis of bacterial numbers and Miss M. Bartel for skilful technical assistance.

\section{LITERATURE CITED}

Ahearn, G. A. and Townsley, S. J. (1975). Integumentary amino acid transport and metabolism in the apodous sea cucumber, Chiridota rigida. J. exp. Biol., 62, 733-752.

Anderson, J. M. (1966). Aspects of nutritional physiology. In R. A. Boolootian (Ed.), Physiology of Echinodermata. Interscience Publishers, New York, London, Sidney. pp. 329-357

Andrews, P. and Williams, P. J. le B. (1971). Heterotrophic utilization of dissolved organic compounds in the sea. III. 
Measurement of the oxidation rates and concentrations of glucose and amino acids in sea water. J. mar. biol. Ass. U. K., 51, 111-125

Bohling, H. (1970). Untersuchungen über freie gelöste Aminosäuren in Meerwasser. Mar. Biol., 6, 213-225.

Bohling, H. (1972). Gelöste Aminosäuren in Oberflächenwasser der Nordsee bei Helgoland: Konzentrationsveränderungen im Sommer 1970. Mar. Biol., 16, 281-289.

Burgh, M. E. de, West, A. B. and Jeal, F. (1977). Absorption of L-alanine and other dissolved nutrients by the spines of Paracentrotus lividus (Echinoidea). J. mar. biol. Ass. U. K., 57, 1031-1045.

Button, D. K. (1978). On the theory of control of microbial growth kinetics by limiting nutrient concentrations. Deep Sea Res., 25, 1163-1177.

Conover, R. J. (1978). Transformation of organic matter. In O. Kinne (Ed.), Marine Ecology, Vol. IV, Dynamics. Wiley, Chichester. pp. 221-499.

Dawson, R. and Pritchard, R. G. (1978). The determination of $\alpha$-amino acids in seawater using a fluorimetric analyser. Mar. Chem., 6, 27-40.

Ferguson, J. C. (1967a). An autoradiographic study of the utilization of free exogenous amino acids by starfishes Biol. Bull mar. biol. Lab. Woods Hole, 133, 317-329.

Ferguson, J. C. (1967b). Utilization of dissolved exogenous nutrients by the starfishes Asterias forbesi and Henricia sanguinolenta. Biol. Bull. mar. biol. Lab., Woods Hole, $132,161-173$.

Ferguson, J. C. (1969), Feeding activity in Echinaster and its induction with dissolved nutrients. Biol. Bull. mar. biol. Lab., Woods Hole, 136, 374-384.

Ferguson, J. C. (1970). An autoradiographic study of the translocation and utilization of amino acids by starfish. Biol. Bull. mar biol. Lab., Woods Hole, 138, 14-25.

Ferguson, J. C. (1971). Uptake and release of free amino acids by starfishes. Biol. Bull mar. biol. Lab., Woods Hole, 141, $122-129$.

Fontaine, A. R. and Chia, F. S. (1968). Echinoderms: An autoradiographic study of assimilation of dissolved organic molecules. Science, N. Y., 161, 1153-1155.

Gocke, K. (1976). Respiration von gelösten organischen Verbindungen durch natürliche Mikroorganismen - Populationen. Ein Vergleich zwischen verschiedenen Biotopen. Mar. Biol., 35, 375-383.

Gocke, K. (1977), Heterotrophic activity. In G. Rheinheimer (Ed.), Microbial Ecology of a Brackish Water Environment. Springer, Berlin. pp. 199-222.

Jørgensen, B. C. (1976). August Pütter, August Krogh, and modem ideas on the use of dissolved organic matter in aquatic environments. Biol. Rev., 51, 291-328.

North, B. B. (1975). Primary amines in California coastal waters: Utilization by phytoplankton. Limnol. Oceanogr., $20,20-27$.

Pandian, T. J. (1975). Mechanisms of Heterotrophy. In $O$. Kinne (Ed.), Marine Ecology, Vol. II, Physiological Mechanisms, Part 1. Wiley, London. pp. 61-249.

Pearse, J. S. and Pearse, V. B. (1973). Removal of glycine from solution by the sea urchin, Strongylocentrotus purpuratus. Mar. Biol., 19, 281-284.
Péquignat, E. (1969). Uptake and assimilation of dissolved nutrients and suspension feeding with both regular and irregular urchins. C. R. Séanc. Soc. Biol., 163, 100-115.

Péquignat, E. (1972). Some new data on skin-digestion and absorption in urchins and sea stars (Asterias and Henricia). Mar. Biol., 12, 28-41.

Siebers, D. and Bulnheim, H.--P. (1977). Salinity dependence, uptake kinetics, and specificity of amino-acid absorption across the body surface of the oligochaete annelid Enchytraeus albidus. Helgoländer wiss. Meeresunters., 29, $473-492$.

Sorokin, Yu. I. (1978). Decomposition of organic matter and nutrient regeneration. In O. Kinne (Ed.), Marine Ecology, Vol. IV, Dynamics. Wiley, Chichester. pp. 501-616.

Sorokin, Yu. I. and Wyshkwarzev, D. J. (1973). Feeding on dissolved organic matter by some marine animals. Aquaculture, 2, 141-148.

Southward, A. J. and Southward, E. C. (1972). Observations on the role of dissolved organic compounds in the nutrition of benthic invertebrates. III. Uptake in relation to organic content of the habitat. Sarsia, 50, 29-46.

Southward, A. J., Southward, E. C., Brattegard, T. and Bakke, $T$ (1979). Further experiments on the value of dissolved organic matter as food for Siboglinum fjordicum (Pogonophora). J. mar. biol. Ass. U. K., 59, 133-148.

Stephens, G. C. (1972). Amino acid accumulation and assimilation in marine organisms. In J. W Campbell and L. Goldstein (Eds), Nitrogen Metabolism and the Environment. Academic Press, New York. pp. 155-184

Stephens, G. C. (1975). Uptake of naturally occurring primary amines by marine annelids. Biol. Bull. mar. biol. Lab., Woods Hole, 149, 397-407.

Stephens, G. C. and Schinske, R. A. (1961). Uptake of amino acids by marine invertebrates. Limnol. Oceanogr., 6 , 175-181.

Stephens, G. C. and Virkar, R. A. (1966). Uptake of organic material by aquatic invertebrates. IV. The influence of salinity on the uptake of amino acids by the brittle star, Ophiactis arenosa. Biol. Bull, mar. biol. Lab., Woods Hole, $131,172-185$

Stephens, G. C., Volk, M. J., Wright, S. H. and Backlund, P. (1978). Transepidermal accumulation of naturally occurring amino acids in the sand dollar, Dendraster excentricus. Biol. Bull. mar. biol. Lab., Woods Hole, 154, 335-347

Taylor, A. G. (1969). The direct uptake of amino acids and other small molecules from sea water by Nereis virens Sars. Comp. Biochem. Physiol., 29, 243-250.

Wangersky, P. J. (1978). Production of dissolved organic matter. In O. Kinne (Ed.), Marine Ecology, Vol. IV, Dynamics. Wiley, Chichester. pp. 115-220.

Williams, P. J. le B., and Gray, R. W (1970). Heterotrophic utilization of dissolved organic compounds in the sea. II. Observations on the response of heterotrophic marine populations to abrupt increases in amino acid concentration. J. mar. biol. Ass. U. K., 50, 871-881.

Williams, P. J. le B., Berman, T. and Holm-Hansen, O. (1976). Amino acid uptake and respiration by marine heterotrophs. Mar. Biol., 35, 41-47.

This paper was presented by Professor H.-P. Bulnheim; it was accepted for printing on June 29, 1979. 